\title{
ESTIMATING THE USEFULNESS OF ICT TOOLS FOR IMPLEMENTING CRITICAL THINKING IN HIGHER EDUCATION
}

\author{
Marko Hell ${ }^{*}$ \\ Ante Kneževic ** \\ Ivan Kekez ${ }^{* * *}$
}

Received: 16. 4. 2021

Preliminary communication

Accepted: 29. 12. 2021

UDC 378.091.33-028.27:330.43

DOI https://doi.org/10.30924/mjcmi.27.1.3

\begin{abstract}
The COVID-19 pandemic interrupted the

learning processes and some opportunities for their implementation. A survey was conducted higher education improvement and highlighted the maintenance of public health as an essential priority. Due to this unexpected situation, the educational system moved from face-to-face to distance learning without prior preparations. This contingency made it possible to study the benefits of ICT tools in the educational process. Starting from the primary function of the educational process and through the forecast of future trends in education, this paper presents the guidelines for improvement of the teaching and among the Faculty of Economics, Business, and Tourism students in Split, Croatia, who evaluated the acceptance of various ICT tools. Based on the obtained research results, generic strategic guidelines for the effective use of IT tools in teaching are presented, including their potential impact on accreditation criteria.

Keywords: COVID-19, ICT tools, critical thinking, teaching, higher education

\section{COVID-19 AS AN}

OPPORTUNITY FOR DIGITAL TRANSFORMATION OF THE TEACHING PROCESSES

COVID-19 pandemic is a public health issue with significant implications for social, economic, and political life. Moreover, epidemiological measures such as social distancing have impacted the educational

system at all levels and will continue to do so for an indefinite period (Reimers, Schleicher, 2020). As COVID-19 became a global problem, educational institutions, in collaboration with country authorities, have taken countermeasures aimed primarily at ensuring academic progress despite epidemic difficulties (Toquero, 2020). Initially, the COVID-19 outbreak was treated as a potentially short-term global crisis, with

\footnotetext{
* Marko Hell, PhD, Associate Professor, Faculty of Economics, Business and Tourism Split, Cvite Fiskovića 5, 21000 Split, Croatia, Phone: +385 21 430716, E-mail: marko.hell@efst.hr

** Ante Knežević, mag. oec., graduate, Faculty of Economics, Business and Tourism Split, Cvite Fiskovića 5, 21000 Split, Croatia, Phone: +385994620 929, E-mail: akneze04@live.efst.hr

${ }^{* * * *}$ Ivan Kekez, mag. oec., graduate, Faculty of Economics, Business, and Tourism Split, Cvite Fiskovića 5, 21000 Split, Croatia, Phone: +38599838 8090, E-mail: ikekez01@live.efst.hr
} 


\section{Journal of Contemporary Management Issues}

the explicit intention of reopening educational institutions after a two-week temporary closure that was later lifted (Zhao, 2020). On February 24, 2020, nearly two months after the newly discovered disease had begun to spread, Croatia confirmed its first recorded case of COVID-19. Due to the continued spread of the disease in the following weeks, Croatian authorities announced a nationwide lockdown on March 16 (Korajlija, Jokić-Begić, 2020). With the outbreak of the epidemic, all educational institutions across the country switched from traditional face-to-face $(\mathrm{F} 2 \mathrm{~F})$ to online learning. Even before the final decision on online education was made, the government of the Republic of Croatia, along with other public agencies, issued general instructions to educational institutions to prepare for the transition of F2F instruction and hybrid models to fully online distance models.

This paper focuses on higher education institutions with specific features compared to others. In a technology-driven environment, higher education institutions provide new learning opportunities to improve the quality of their services further so they can prosper based on their status quo and strategic plans for the future (Aithal, Aithal, 2019). Therefore, due to their practical and academic differentiation, higher education institutions have a high degree of autonomy in implementing e-learning models in education. Due to the described conditions, all teaching models are based on measures resulting from the country's epidemiological situation. The rapid transition to fully online distance education has significant implications for students, instructors, and educational institutions and leaves many questions unanswered (Adnan, Anwar, 2020).

Online learning can be defined as distance education delivered through technological solutions that do not require instructors and learners to be available simultaneously (Glasby, 2015). Although online learning was not an unknown concept in education, it became more valuable during the outbreak of the epidemic, offering opportunities to conduct educational processes in new conditions with more accessibility, flexibility, and cost-effectiveness, but also with some undeniable risks (Ferr et al., 2020; Dhawan, 2020).

Technological development was rapid, and many educational institutions did not have enough time and resources to make the advanced changes that new opportunities bring in the digital age (Glasby, 2015). In addition, some authors expressed concerns about institutional capacity to transform traditional education by adopting and applying technological tools as practical supports for existing learning experiences (Glasby, 2015; Zhao, 2020). A global survey conducted by the International Association of Universities (IAU) found that not all higher education institutions worldwide could immediately shift from the existing teaching model to a new way of learning. Some institutions temporarily suspended most of their teaching, and some canceled classes altogether. However, the regional analysis showed that a high percentage $(97 \%)$ of educational institutions had adequate technical infrastructure and accessibility for online learning. Most higher education institutions with canceled classes were mainly located outside Europe (Marinoni et al., 2019).

Online learning in higher education depends mainly on providing a technical infrastructure. In addition, higher education institutions must prioritize education based on available resources (Adnan, Anwar, 2020). Significant concerns were how to ensure that students master the content taught 
by instructors in an online environment and how instructors should encourage students to participate in the entire learning process (Zhao, 2020). Some identified factors for implementing an effective online teaching and learning environment are modeling online practices, ensuring interactions between participants in the online environment, transferring all knowledge content online, and navigating the available tools and technologies (O'Brien et al., 2020). Furthermore, this may vary based on the different areas of study in which reliance on specific tools and technologies changes. For example, online learning models may not provide the necessary practical knowledge in fields such as medicine. At the same time, online learning in computer science can be very effective as long as educational institutions can provide the essential tools for online learning (Marinoni et al., 2019).

Accordingly, teaching methods have become a matter of strategic importance in higher education. Due to the sensitivity of the whole digital transformation of the teaching process, it is necessary to approach the problem systematically and use new approaches in combination with existing methods to evaluate the impact of ICT (information and communication technology) tools in education. Only in this way is it possible to use such a situation to improve deficiencies in existing teaching processes where possible, which is the main objective of this research paper. This paper provides guidelines on how using ICT tools can enhance the teaching process related to developing students' critical thinking in higher education. The empirical research was conducted at the Faculty of Economics, Business and Tourism (FEBT) in Split, Croatia, and the authors will present their findings in the case study.

\section{USE OF ICT TOOLS AND EDUCATION EFFICIENCY}

Due to the COVID-19 measures, teaching and learning are often technology-oriented. Unfortunately, before this pandemic, technology in the classroom primarily served to convey information rather than support and encourage engagement. Furthermore, there are three relevant components to making the e-environment work for learning: pedagogical models and constructs, teaching and learning strategies, and, last but not least, pedagogical tools for online learning strategies (Glasby, 2015).

In addition, COVID-19 epidemiological measures have in some ways "forced" higher education institutions into e-learning. This is important to note because it raises whether institutions will revert to old habits after the pandemic or incorporate some of the 'pandemic behavior' into their daily activities.

Higher education faces technological change, intense competition, and scarce resources, requiring the optimal online and face-to-face instruction mix. To this end, it is necessary to determine the focus of educational improvement, the roles of stakeholders in the teaching process, and the contribution of ICT to teaching/learning (Glasby, 2015).

\subsection{Development of students' critical thinking in higher education}

Learning is an active process in which people construct new knowledge through exploration, experimentation, discussion, and reflection (Resnick, 2002). Critical thinking (CT) is an essential aspect of learning is critical thinking (CT), which contributes to problem-solving and decision-making in individuals' personal and professional lives. Thus, educational 


\section{Journal of Contemporary Management Issues}

institutions need to recognize the importance of building CT skills in students. Unfortunately, there is a strong emphasis on 'learning facts' in exam-oriented cultures, which is often detrimental to the development of CT skills, even though the opposite is often claimed (Razaei et al., 2011).

Empirical research suggests that people with fluid reasoning, a concept closely associated with CT, outperform others in producing creative ideas and are far better at fostering creative thinking (Nusbaum, Silva, 2011). Therefore, teachers should engage students through questioning, discussion, and reflection and use as many active learning methods as possible that provide the best solution for the benefit of CT. Moreover, if students have enough time to think about, discuss, or elaborate on the question, they are more likely to use advanced CT skills (Razaei et al., 2011).

It can be said that the essence of implementing CT is always the same. However, different methods are used in the classroom and the online environment. In other words, the same methods can often not be used to promote CT in face-to-face and online classrooms. For example, in the classroom, teachers need to ask students to recall the information, require students to explain why, allow them to demonstrate something, ask them to make an analysis and judgment, and ask students to think of different approaches to the task (Norfleet, 2017). On the other hand, in a Moodle-based Learning Management System, CT can be achieved through various options such as Quick Messaging, Industry Exposure, Forums, Quality Assessments, Feedback, etc. (Duque, 2019).

\subsection{Student-centered teaching: A process approach}

The standard ISO 9001 explains that a process is a set of interrelated or interacting activities that use inputs to deliver an intended result (International Organization for Standardization, 2015). It can also be said that a process is something that stakeholders in a particular process do to achieve a specific goal (Servan, 2019). The authors of this paper emphasize the process approach because it is learner-centered. This means that learners' needs, learning styles, goals, and abilities are all considered in the learning process (Satya Sri Durga, Sekhar Rao, 2018)

For higher education processes, it is essential to know who is doing it (there are three different types of stakeholders - teachers, students, and employers), when it is done (teachers and students are not present at the same time, regardless of the teaching environment), how it is done (including traditional face-to-face teaching, distance learning, online learning, hybrid learning, collaborative online learning, and open educational resources), what it takes (integrating pedagogy, technology, and space), and how it can be seen to work effectively (curriculum must be aligned with labor market needs) (Glasby, 2015).

As stated earlier, modern education is responsible for developing $\mathrm{CT}$ skills in students. This means a reorientation from adopting and reproducing empirical facts to developing CT skills (Pešić, 2003). Based on the standard procedure defined by the Croatian Qualifications Framework, the authors of this paper assume that the labor market requirements match the curriculum. This is not the focus of the research paper, so the authors decided not to go into further detail. 
When implementing CT concepts into the educational process, it is imperative to choose an appropriate model. Because of its scope and simultaneous simplicity, the authors propose the Evocation - Realization of meaning - Reflection (ERR) model, which is well known in the literature. Briefly, the ERR model consists of three phases - in the first phase, students have to remember what they have already learned. Therefore, the teacher asks for active participation and motivates students for the new lecture. In the second phase, the teacher imparts knowledge about the lesson, plays a significant role in building students' knowledge, and requires interaction while maintaining a cooperative relationship. Finally, in the third phase, the teacher links the prior knowledge to the new lecture and asks the students to present it in their own words. This model is more suitable for real-time classroom instruction, but this does not mean that it cannot be integrated into an online environment (Akalović Antić et al., 2016). It is essential to mention that the mismatch between the teaching and learning styles can lead to learning failure and general problems such as lack of motivation and insufficient prior knowledge of students (Cota Bekavac et al., 2005).

\subsection{Using ICT tools for a more efficient teaching process}

There are some strong concerns about the ineffective use of digital technology in higher education institutions. This suggests that they do not realize the full potential of ICT tools to enhance student learning experiences (Glasby, 2015). At the same time, there should always be evidence that changes in the teaching process that include increased use of ICT tools have improved student learning. Thus, the following questions can be used as a guide to determine whether the inclusion of ICT tools contributes to a more effective teaching process (Kirkwood, Price, 2014):

- What is improved when ICT tools are integrated into the teaching process?

- How will the improvement achieve, and how can it be determined?

- Are the improvements related to the increased use of ICT tools?

- Does the use of ICT tools improve teaching practices and student learning outcomes?

\section{USE ASSESSMENT OF ICT TOOLS IN HIGHER EDUCATION}

Teaching can be organized in four different ways: 1) same time - same space, 2) same time - other space, 3 ) other space - same time, and 4) different time - different space. Each of these can be achieved using various ICT tools, and all pedagogical norms should be followed whether ICT tools are used or not. Nevertheless, ICT in higher education can transform teaching and learning (Ghavifekr et al., 2016). However, it is necessary to note that the impact of ICT on an organization must be systematic to monitor the effect on the organization's business goals. In addition, it is essential to choose an appropriate method that provides guidelines for the use of new ICT tools. For this paper, the authors chose SWOT analysis as a proper method. Below is a brief description of the SWOT analysis in the context of the deployment of new ICT tools.

\subsection{SWOT analysis}

The matrix analysis approach is used in this paper because matrices reduce a seemingly infinite continuum of alternatives to 


\section{Journal of Contemporary Management Issues}

a manageable number of discrete options from which higher-order directions can be determined. Matrices are useful in helping decision-makers make informed choices about how ICT tools should be implemented in higher education institutions (Ward, 1987).

The process of identifying the role of the portfolio of online tools to be implemented must be entirely focused on creating an effective teaching process. Therefore, customized SWOT analysis for ICT is used. One method is based on analyzing the impact of online technologies in teaching. This means that it is necessary to consider all the opportunities $(\mathrm{O})$ and threats ( $\mathrm{T})$ of using available online technologies as external factors for the quality of teaching processes. Another aspect is accepting online technologies in teaching as internal strengths (S) and weaknesses (W) of a particular higher education institution.

Table 1. shows guidelines for using the new ICT tools in the classroom based on the analysis of SWOT. Each cell represents a different strategy that higher education institutions will operate according to their strengths, weaknesses, threats, and opportunities. Thus, a given higher education institution has four different strategies at its disposal. After that, the institution needs to define activities, actions, and goals and find the necessary resources to implement the strategy. Implementing an $(\mathrm{O}, \mathrm{S})$ strategy based on opportunities and strengths will undoubtedly lead the institution to achieve the desired improvements in teaching. Identifying the available ICT tools (opportunity) and weaknesses for their applicability in teaching to achieve the desired impact carries a high risk. Therefore, it is necessary to identify $(\mathrm{O}, \mathrm{W})$ strategies that will address the perceived weaknesses by applying the strengths of ICT tools. Incorrect or incomplete use of ICT tools, for example, requires additional training for teachers to take full advantage of all the capabilities of a particular ICT tool.

Specific technological solutions may present threats $(\mathrm{T})$ to achieve desired effects. For example, existing licensed software solutions may not be usable in an online environment. In addition, updating them usually involves a significant increase in cost. For this reason, it is necessary to use existing resources (S) to find alternatives. However, by their definition, threats are external factors that cannot be eliminated, only averted. Therefore, it is crucial to exhaust all possibilities to protect higher education institutions, even if this means not using new ICT tools.

The internal SWOT elements $(\mathrm{S}, \mathrm{W})$ for ICT use in teaching are based on the current organizational resources. On the other hand, the focus on students requires an investigation of student preferences in implementing all teaching activities. Thus, it is possible to determine the most appropriate way of teaching based on the importance of the end-users - the students. 
Table 1. Guidelines for the use of new ICT tools (based on the SWOT analysis)

\begin{tabular}{|l|l|l|l|}
\cline { 2 - 4 } \multicolumn{2}{l|}{} & Strengths $(S)$ & Weaknesses $(W)$ \\
\hline \multirow{2}{*}{$\begin{array}{l}\text { Effect assessment } \\
\text { of the new ICT } \\
\text { tools }\end{array}$} & Opportunities $(O)$ & $\begin{array}{l}\text { Use of new ICT tools with } \\
\text { expected success }\end{array}$ & $\begin{array}{l}\text { Be careful when using new } \\
\text { ICT tools }\end{array}$ \\
\cline { 2 - 4 } & Threats $(T)$ & $\begin{array}{l}\text { Explore and identify } \\
\text { opportunities to use new ICT } \\
\text { tools }\end{array}$ & $\begin{array}{l}\text { Protecting the organization } \\
\text { with the use of new ICT tools }\end{array}$ \\
\cline { 2 - 4 } & Ability to accept new ICT tools in an organization \\
\cline { 2 - 4 }
\end{tabular}

Source: Authors

\section{FEBT - CASE STUDY}

As mentioned earlier, the processoriented approach to the teaching process focuses on the end-user, i.e., the student. The bearers of the teaching process are the teachers. This means that they must adapt the curriculum's implementation without compromising the learning outcomes. However, the use of ICT tools should be aligned with teaching models. In line with future trends in higher education, particular emphasis is placed on the applicability of ICT tools in teaching.

\subsection{Assessing student preferences in the delivery of instructional activities}

Due to the COVID-19 pandemic and the epidemiological situation in the Republic of Croatia, the summer semester in the academic year 2019/20 was conducted entirely by distance learning, using the available ICT tools. Based on the students' experiences during the distance learning, a survey was conducted to determine the desired teacher profile as understood by the students, their preferences in adopting the teaching materials, and their preferences in assessing the learning outcomes. In responding to the survey, students were instructed to be guided by their preferences for various aspects of teaching rather than by potential problems or limitations. The survey was anonymous, and 306 students participated, with roughly equal representation from all levels and types of study.

The survey was divided into four sections:

- Student profile: this set of questions aims to identify students' desires and ambitions, learning styles, and abilities to use ICT tools in the classroom.

- Desired teacher profile: it is necessary to identify what qualities students think an 'ideal' teacher has concerning different aspects of teaching (quality of lectures, motivational and organizational skills, quality of organization and preparation of teaching materials, and IT skills).

- Students' preferences regarding teaching in all phases of the ERR model. 


\section{Journal of Contemporary Management Issues}

- Student preferences regarding the assessment of learning outcomes.

Comparing the responses in each category made it possible to conclude students' preferences regarding how the instructional process is conducted, describing their willingness (ability) to accept ICT tools in the classroom. Below is a general overview of the analysis undertaken. The numbers represent an average score between 1 and 5 .

Students rated the importance of having all the conditions for attending classes from home (good internet connection, study room, etc.) as 4.468 . In addition, they rated their skills in using different tools as follows: Communication tools (4.606), Moodle platform tools (4.612), video conferencing tools (4.144), and electronic work creation tools (4.21). This indicates that students have the necessary infrastructure, knowledge, and skills in using ICT tools, which is a prerequisite for successful distance education.

In the segment related to the evaluation of the importance of the criteria of the 'ideal' teacher, the students mentioned as the most important criteria: Quality of lectures (4.8), motivational skills (4.57), and quality in organization and preparation of teaching materials (4.66). Regarding the quality of the course, students consider the use of practical examples (4.76) and the regular and precise answering of questions by the lecturer (4.82) as the most important criteria. When it comes to the instructor's motivational skills, students highlight accepting different ideas and opinions (4.58). The instructor must encourage students to express their views, make critical judgments, and reconsider attitudes (4.30). Finally, students highlighted the criterion that authoritative literature is available and easy to understand (4.48). It can be concluded that students prefer a passive form of learning, with the understandable literature and the teacher's availability serving as enablers of the adoption of the teaching material, without (or minimal) teacher involvement in the discussions and development of CT.

The importance of the phases of instruction (as modeled by ERR) was rated as follows: repetition of previous material is necessary for the adoption of the new material (3.99) while teaching the new material and adoption of the material by combining old and new material is equally important (4.47). The best ways to review the old material are short F2F presentations by teachers (3.92) and short presentations via video conferencing (3.46). Other criteria based on student involvement were rated lower. In addition, F2F lectures and exercises and recorded lectures with the possibility of asking teachers questions via email or message are essential criteria in the second ERR phase (with the same score - 3.86). In the last phase, where students have to combine old and new material, students prefer the use of self-assessment tools (3.81), teamwork on various project tasks (3.52), and group discussions using forum tools on given topics (3.32). As before, students prefer independence without active teacher involvement. Team assignments and group discussions provide an exceptional opportunity for active student participation and teamwork.

The last but not least important part of the survey is related to the dynamics and ways of assessing learning outcomes. The following criteria were highly rated: assessment of all activities throughout the teaching process (responses, tests, essays, project assignments) (4.16) as well as review in the form of weekly assignments (3.61) and review in the form of student reflections on given case studies (3.65). This indicates that students prefer continuous assessment of all activities in the teaching process. 


\subsection{Assessment of ICT impact on students' preferences in teaching process: Survey results}

Based on the overall survey results on student preferences regarding the instructional process, it can be stated that:

- students have sufficient technical knowledge, skills, and opportunities to work remotely,

- students recognize the importance of clarity and availability of instructional materials,

- $\quad$ students support the inclusion of practical examples in the teaching process,

- student involvement in the teaching process is preferred in writing through forums, open discussions, and team assignments,

- there is an existing requirement for self-assessment tests per learning outcome,

- continuous assessment of all student activities should be included in the teaching process.

Based on the above, it can be said that there is more than enough room for further improvement of the teaching process following the students' preferences.

The teaching process should start with uploading and providing appropriate teaching materials on a given LMS platform. To improve the quality of the teaching material, it is recommended that students engage with the material to check their understanding. Likewise, formulating questions for teachers can also serve as preparation for future lectures. This type of student activity should be appreciated and lead to an improvement in the teaching process.
In addition, it is necessary to use the available ICT tools to promote open discussions and student collaboration. Due to the lack of student motivation to actively engage in the classroom, these activities should be approached with caution, and workshops could be organized for teachers to take advantage of these tools' technological possibilities. The desired level of motivation among students can be achieved by evaluating and appreciating the efforts of students who actively participated in the different types of tasks, thereby stimulating the dynamic behavior of other students in future activities. After completing the specific instructional material that defines a learning outcome, it is imperative to introduce self-assessing tests provided by ICT tools. The authors suggest that the tests should not be used in the final formation of the course grade, but they can be considered a condition for exam registration as a motivating factor for students. Moreover, from the students' point of view, the approach to this activity should lead to higher efficiency of the teaching process and better final results.

The main risk in distance learning is the risk of lower authenticity of students' work uploaded on LMS platforms. However, there is direct contact between students and teachers in blended learning models. This segment of traditional instruction opens the possibility of verifying the authenticity of student work. This means that most activities, including learning, hands-on research and assigned tasks, and self-assessment of acquired knowledge, can be completed remotely.

Verification of the authenticity of completed tasks can be achieved through a traditional teaching model. Therefore, continuous assessment of all teaching and learning activities is carried out, and at the same 


\section{Journal of Contemporary Management Issues}

time, students should be motivated to participate in the teaching process actively. This mixed teaching activity will ensure students' independent work level following ECTS credits.

The obtained results on student preferences, the status of available resources on
FEBT, and available ICT tools provide a tabular overview of strategic guidelines to improve the efficiency of the teaching process. These strategic guidelines are organized by quadrant and are consistent with the expected outcomes, presented in Table 2.

Table 2. Strategic guidelines for improving the efficiency of the teaching process

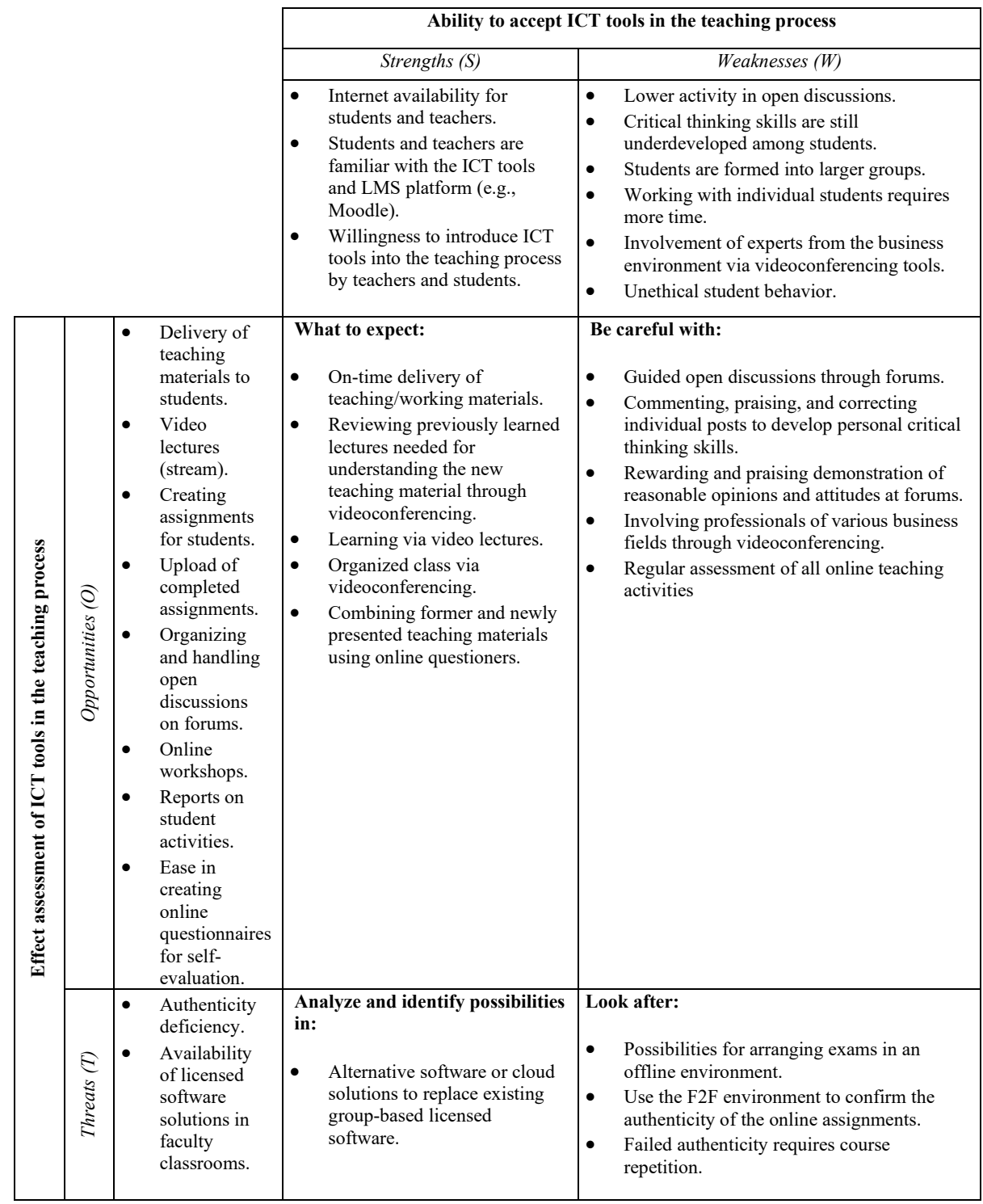

Source: Authors 


\subsection{The expected contribution of implementing the strategic guidelines to the accreditation process}

Every five years, FEBT goes through a mandatory institutional accreditation process by the Agency for Science and Higher Education (ASHE) to obtain an educational license for its main activities: teaching, science, and lifelong learning. In addition, FEBT demonstrates the quality of its work through numerous international accreditations to strengthen its international visibility and position alongside leading international higher education and scientific institutions. In addition, accreditation provides an opportunity to position itself as an institution aligned with the current needs of the labor market and economy, provides students with an excellent value and recognition of their degrees, and promotes the development of students' competencies.

The expected contributions of implementing the strategic directions according to the selected accreditation standards are listed below. FEBT's rank is expected to increase to at least the next higher level for each standard.

- Continuously consider the relevance and practicality of study programs in collaboration with stakeholders and introduce changes to study programs, learning outcomes, and teaching processes by collected feedback (ASHE2-1): the primary focus of this analysis is on students (learner-centered approach). In addition, LMS platforms such as Moodle allow faculty to monitor various reports on student activity.

- Consider implementing a program of study delivered entirely in English or online (or multiple courses using the Moodle platform) (ASHE-2-2): implementing these strategic guidelines is a prerequisite for developing the overall teaching process of each subject on the Moodle platform.

- Students are provided with the most modern teaching materials possible (ASHE-3-1): incorporating more ICT tools into the classroom requires modern teaching materials.

- Increase the number of guest lecturers from the field and teach more valuable content to students. (EPAS-1-1): The advent of distance learning will make it easier to bring in practitioners from different locations. This has been one of the significant problems.

- Enhance the academic dimension of student work within the course and in writing final/graduate papers (EPAS-12): applying new concepts in the strategic guidelines will increase critical thinking. This is a long-term contribution related to the criterion.

\section{CONCLUSION}

International crises, such as the COVID-19 pandemic may lead to a better selection of available solutions. Therefore, these solutions may also allow for better adaptation to new circumstances. As related to the choice of offline vs. online teaching models, there is little room for adaptation. On the other hand, the availability of various information is enormous and creates a false sense of knowledge in any field. Therefore, the ability to draw quality conclusions for further development is questionable. Regardless of the new COVID-19 situation, the quality of the teaching process is questioned. This paper focuses on developing critical thinking as one of the main goals in higher education. The authors used the process approach and adopted the view 


\section{Journal of Contemporary Management Issues}

of students as end-users of the teaching process. Thus, the critical factor of this paper is to highlight the importance of students' perception and the possibilities of using ICT tools in the teaching process. The survey conducted at the Faculty of Economics, Business and Tourism revealed students' preferences in ICT and its implementation in the teaching process. Using the SWOT analysis, the authors analyzed the impact of ICT tools and identified strategic guidelines that should improve the teaching process.

\section{References}

1. Adnan, M. and Anwar, K., (2020). Online learning amid the COVID-19 pandemic: Students' perspectives. Journal of Pedagogical Sociology and Psychology, 2(1), 45-51. doi: 10.33902/ JPSP. 2020261309

2. Aithal, P.S. and Aithal, S. (2019). Autonomy for Universities Excellence - Challenges and Opportunities. International Journal of Applied Engineering and Management Letters, 3(2), doi:10.5281/zenodo.3464710.

3. Akalović Antić, J., Harmina, A., and Meter, J., (2016). Primjena ERR okvira na nastavnu jedinicu: aritmetička sredina. Poučak: časopis za metodiku $i$ nastavu matematike, 17 (65), 5-20.

4. Cota Bekavac, M., Grozdanić, V. and Benge Kletzien, Sh., (2005). Aktivno učenje i kritičko mišljenje u visokoškolskoj nastavi. Priručnik za nastavnike - Suradničko i iskustveno učenje. Zagreb: Forum za slobodu odgoja.

5. Dhawan, S., (2020). Online Learning: A Panacea in the Time of COVID-19 Crisis. Journal of Educational Technology Systems, 49(1), 5-22. doi: $10.1177 / 0047239520934018$
6. Duque, T. C., (2019). Critical Thinking In Moodle-Based LMS: The What, Why \& How. https://www.lmspulse. com/2019/critical-thinking-in-moodle-based-lms-the-what-why-how/ [Accessed 05.11.2020.]

7. Ferr, F., Grifoni, P., and Guzzo, T., (2020). Online Learning and Emergency Remote Teaching: Opportunities and Challenges in Emergency Situations. Societies, 10(4), 86. doi: 10.3390/soc 10040086

8. Ghavifekr, S., Kunjappan, T., Ramasamy, L., Anthony, A., (2016.) Teaching and Learning with ICT tools: Issues and Challenges from Teachers' Perceptions. Malaysian Online Journal of Educational Technology, 4(2)38-57.

9. Glasby, P., (2015). Future trends in teaching and learning in higher education, Institute for Teaching and Learning Innovation, https://web.archive.org/web/20160307202331/https://itali.uq.edu.au/filething/get/3419/ Final_Future trends_in teaching and learning_in_higher_education3.pdf

10. International organization for standardization (2015), The Process Approach in ISO 9001:2015, https://www.iso. org/files/live/sites/isoorg/files/archive/ pdf/en/iso9001-2015-process-appr.pdf

11. Kirkwood, A. and Price L., (2014). Technology-enhanced learning and teaching in higher education: What is 'enhanced' and how do we know? A critical literature review. Learning, Media and Technology, 39 (1), 6 - 36

12. Korajlija, A.L. and Jokić-Begić, N., (2020). COVID-19: Concerns and behaviours in Croatia. British Journal of Health Psychology. doi: 10.1111/ bjhp. 12425

13. Marinoni, G., Van't Land, H., and Jensen, T., (2019). The impact of 
COVID-19 on higher education around the world. International Association of Universities (IAU). https://www. iau-aiu.net/IAU-Global-Survey-onthe-Impact-of-COVID-19-on-HigherEducation-around-the

14. Norfleet, M., (2017). What Are the Steps to Critical Thinking According to Bloom's Taxonomy? https://classroom. synonym.com/blooms-relate-criticalthinking-information-6233382.html]

15. Nusbaum, C., E. and Silvia, J., P., (2011). Are intelligence and creativity really so different? Fluid intelligence, executive processes, and strategy use in divergent thinking. Intelligence, 39(1), 36-45, doi: 10.1016/j.intell.2010.11.002

16. O’Brien, W., Adamakis, M., O’ Brien, N., Onofre, M., Martins, J., Dania, A., Makopoulou, K, Herold, F., Ng, K. and Costa, J., (2020). Implications for European Physical Education Teacher Education during the COVID-19 pandemic: a cross-institutional SWOT analysis. European Journal of Teacher Education., 503-522. doi: 10.1080/02619768.2020.1823963

17. Pešić, J. (2003). Kritičko mišljenje između pomodarstva i promišljanja: ka teorijskom utemeljenju koncepta $\mathrm{u}$ : Psihologija 36(4); 411-423.

18. Razaei, S., Derakshan, A., and Bagherkazemi, M., (2011). Critical thinking in language education. Journal of Language Teaching and Research, 2(4), 769-777. doi: 10.4304/ jltr.2.4.769-777
19. Reimers, M. F. and Schleicher A., (2020.) A framework to guide an education response to the COVID-19 Pandemic of 2020. https://oecd.dambroadcast.com/pm_7379_126_126988t631xosohs.pdf_[Accessed 20.03.2021.]

20. Resnick, M., (2002.) Rethinking learning in the digital age. The Global Information Technology Report: Readiness for the Networked World. Oxford University Press, 32-37.

21. Satya Sri Durga V., Rao, C.S. (2018) Developing Students' Writing Skills in English - A Process Approach. Journal for Research Scholars and Professionals of English Language Learning, 2(6), ISSN: 2456-8104.

22. Servan, P., (2019). Process-based Approach. https://factorquality.com/ process-approach/

23. Toquero, C. M. (2020). Challenges and Opportunities for Higher Education amid the COVID-19 Pandemic: The Philippine Context. Pedagogical Research, 5(4), em0063. doi: $10.29333 / \mathrm{pr} / 7947$

24. Ward, J. (1987) Information System and Technology Application Portfolio Management - An Assessment of Matrix-Based Analyses. Journal of Information Technology, 3(3) doi: 10.1057/jit.1988.36_

25. Zhao, Y., (2020). COVID-19 as catalyst for educational change. Prospects, 49, 29-33. doi: 10.1007/ s11125-020-09477-y 


\title{
PROCJENA KORISNOSTI INFORMATIČKO- KOMUNIKACIJSKIH (IKT) ALATA ZA PROVEDBU KRITIČKOG RAZMIŠLJANJA U VISOKOM OBRAZOVANJU
}

\begin{abstract}
Sažetak
Pandemija COVID-19 zaustavila je unapređenje visokog obrazovanja i stavila naglasak na održavanje javnog zdravlja kao ključni prioritet. Zbog ove neočekivane situacije, obrazovni sustav se, bez posebne pripreme, preorijentirao $s$ tradicionalne fizičke nastave na obrazovanje na daljinu. Ova je okolnost olakšala analizu koristi od IKT alata u obrazovnom procesu. Polazeći od primarne funkcije obrazovnih procesa i predviđa-

njihovu primjenu. Među studentima Ekonomskog fakulteta u Splitu, u Hrvatskoj, provedeno je anketno istraživanje, na temelju kojeg se evaluira prihvaćanje različitih IKT alata. Na temelju rezultata istraživanja, prezentiraju se generičke strateške smjernice za učinkovitu uporabu IKT alata u podučavanju, uključivši $i$ analizu njihovog potencijalnog djelovanja na akreditacijske kriterije.
\end{abstract} nja budućih obrazovnh trendova, u ovom se radu predstavljaju smjernice za unapređenje procesa učenja i podučavanja, kao i neke mogućnosti za
Ključne riječi: COVID-19, IKT alati, kritičko razmišljanje, podučavanje, visoko obrazovanje 